\title{
Siting Consideration for Nuclear Power Plant: A Review
}

\author{
M.A.Khattak ${ }^{1}$, Abdoulhdi Amhmad Borhana Omran ${ }^{2}$, Ali Najah \\ Ahmed $^{3}$, Aishah Umairah ${ }^{1}$, Mohamad Amirudin Mohamad Rosli ${ }^{1}$, \\ Syeheer Sabri ${ }^{1}$, Mohammad Akmal Saad ${ }^{1}$, Mubin Solehan Abd. \\ Hamid $^{1}$, S.Kazi ${ }^{4}$ \\ ${ }^{1}$ Universiti Teknologi Malaysia, Skudai, Johor, Malaysia \\ ${ }^{2}$ Sebha University, Sebha, Libya \\ ${ }^{3}$ Universiti Tenaga Nasional, Selangor, Malaysia \\ ${ }^{4}$ Isra University, Hyderabad Campus, Pakistan \\ *Corresponding Author: Abdoulhdi Amhmad Borhana Omran:
borhana73@yahoo.com
}

\section{OPEN ACCESS}

Citation: Khattak M.A., Omran A. A. B., Ahmed A. N., Umairah A., Rosli M. A. M., Sabri S., Saad M. A., Hamid M. S. A., Kazi S. (2017) Siting Consideration for Nuclear Power Plant: A Review Open Science Journal 2(3).

Received: $25^{\text {th }}$ May 2017.

Accepted: $10^{\text {th }}$ July 2017.

Published: $29^{\text {th }}$ July 2017.

Copyright:@ 2016 This is an open access article under the terms of the Creative Commons

Attribution License, which permits unrestricted use, distribution, and reproduction in any medium, provided the original author and source are credited.

Funding: The author(s) received no specific funding for this work.

Competing Interests: The author have declared that no competing interests exists.

\section{Abstract}

The purpose of this research is to study in detail about the site selection process in nuclear power plant (NPP) construction. There are various factors that contribute to the site selection which involves indepth investigation and detailed evaluation before the site is being finalized and proposed. There are two main objectives in siting of NPP; ensuring the technical and economic feasibility of the plant and minimising potential adverse impacts on the community and environment. Geographical environment also plays an important role in siting of NPP where the source of water should be abundance. Country requirement for siting of NPP would be different for every country where they are controlled by their own regulatory bodies. About 64 published studies (1967-2017) are reviewed in this paper. It is marked from the literature survey articles that siting process is extremely crucial step in constructing NPP where public acceptance is one of the main factors, that need to be considered. Malaysia is one of the new countries embark in nuclear industry that still is in the planning phase to plan and construct its first NPP.

Keywords: Site selection, Nuclear power plant, Safety, Country requirement, Public acceptance, Geographical environment 


\section{Introduction}

Site selection is one of the vital steps in designing nuclear power plant (NPP). Different places provide different analyses of sites and resulting in different type of nuclear station that suitable to build. The selection of suitable site is the result of a process in which the costs are minimized [1]. This step involves the investigation of a large region to select preferred sites and followed by detailed evaluation of the preferred site.

In discussing the site selection process, the following list is important. They are region of interest, candidate areas, potential sites, candidate sites, acceptable sites and preferred sites. This list should be discussed with detail. In the process of selecting site for construction of nuclear power plant, the factors need to be discussed: geologic/seismic, hydrologic, and meteorological characteristics of proposed sites, determination of exclusion area and low population zone, population considerations as they relate to protecting the general public from the potential hazards of serious accidents, potential effects on a plant from accidents associated with nearby industrial, transportation, and military facilities, emergency planning and security plans [1].

The objective of this paper is to review the siting process that countries that used nuclear power as their electricity generator had undergone. This paper includes all information that listed above.

\section{Analysis and Discussion}

\section{Analysis of Nuclear Power Plant Worldwide}

\section{History of the Discovery of Nuclear Activity}

For centuries, pottery makers used uranium oxide in their ceramics to obtain a yellow tint to the ceramic glazes, but yet they did not know the properties and the dangerous they were dealing with. Radioactive materials also can be found in clocks, watches and dials that glow in the dark without the use of battery and Vaseline glass or canary glass that contains uranium in small amounts, which is why the glass was called canary. Some of the watches contained as much as 4.5 $\mu \mathrm{Ci}$ of radium [2].

The first person who discovered the properties of earth's crust element was Antoine Henri Becquerel during he carried out experiments with fluorescence and phosphorescence. He found out after putting some wrapped photographic plates away in a darkened drawer, along with some crystals containing uranium, the plates had been exposed by invisible emanations from the uranium [3]. The discovery made by Becquerel was an accident. This happened when Becquerel decided to investigate whether there was any connection between X-rays and naturally occurring phosphorescence where he inherited from his father a supply of uranium salts, which phosphorescence on exposure to light [4]. Becquerel also found out that the rays emitted by uranium could ionized the gas and they were different from X-ray where they count be deflected by electric or magnetic fields $[4]$. 


\section{World Status on Nuclear Industry by 2015}

By 2015, there were 30 countries are in operation of nuclear power plants with a total of 391 reactors and combined installed capacity of 337 GW [5]. By 2014, there were five reactors have been started where three in China, one in Argentina and one in Russia, meanwhile there was one was shut down which was in Vermont Yankee in the US. By the middle of the year of 2015, there were five reactors have been started where four in China and one in South Korea, meanwhile two were shut down which one in Belgium and one in Germany. By 2014, no power plant has been generated in Japan and World Nuclear Industry Status Report (WNISR) classified 40 Japanese reactors as being in Long-Term Outage (LTO) [5]. In 2014 too, one reactor in Sweden that had been early closure and two units that were in LTO. Meanwhile, in 2015, one reactor in South Korea was restarted in June, and one reactor in India was to be decommissioning. In July 2015, two reactors were restart in Japan. By 2014, $69 \%$ of generated electricity in the world is come from nuclear power plant and the "big five" nuclear generating countries by rank were United States, France, Russia, South Korea and China. By 2015, only China has major new-build programs and the average life of nuclear reactors in the world was 28.8 years. Over half of the total, or 199 units have operated for more than 30 years, including 54 that have run for over 40 years [5]. By July 2015, 62 reactors were under construction with total capacity of 59 GW and almost $40 \%$ of the projects (24) are in China [5]. In 2014, there was one being built in Argentina, Belarus and United Arab Emirates but no new construction in China.

Following are the data collected by the year of 2015 on about the electricity generated by nuclear.

Figure 1: Nuclear Electricity Generation in the World [6]

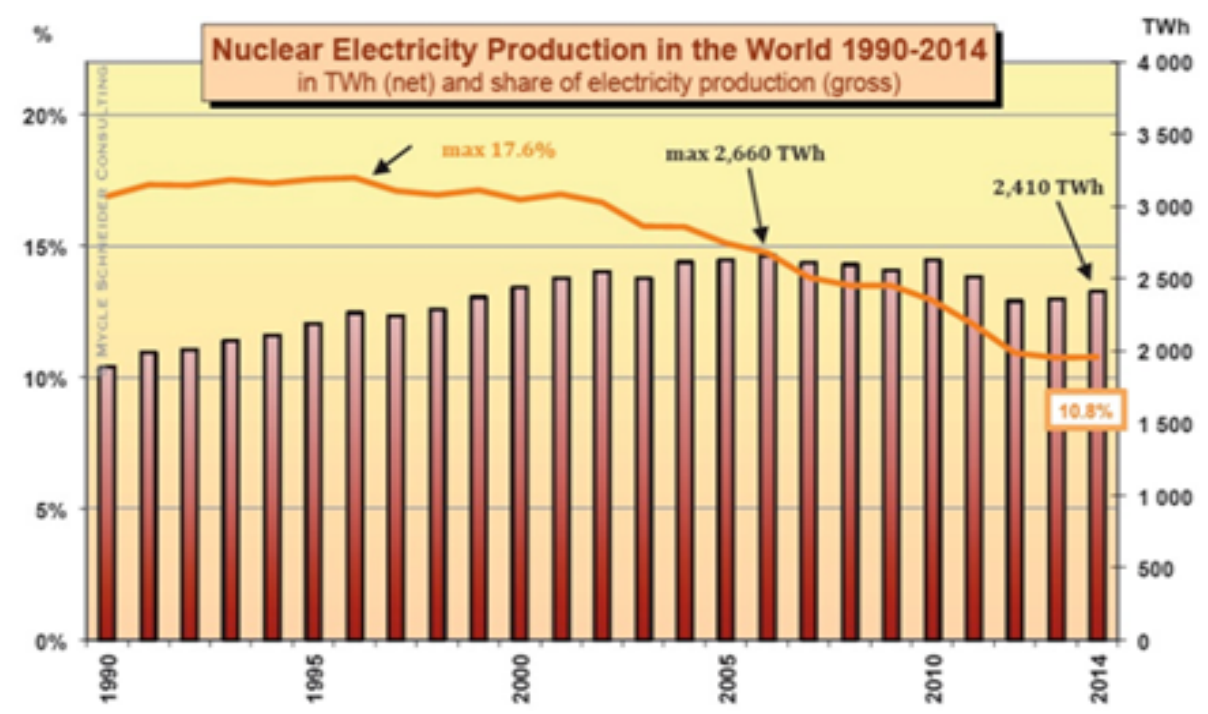


Table 1: Nuclear Reactors "Under Construction" (as of 1 July 2015)

\begin{tabular}{|c|c|c|c|c|c|}
\hline Country & Units & $\begin{array}{l}\text { MWe } \\
\text { (net) }\end{array}$ & $\begin{array}{c}\text { Construction } \\
\text { Start }\end{array}$ & $\begin{array}{c}\text { Grid } \\
\text { Connection }\end{array}$ & $\begin{array}{l}\text { Delayed } \\
\text { Startup } \\
\text { (Units) }\end{array}$ \\
\hline China & 24 & 23738 & 2009-2015 & $2015-2021$ & 15 \\
\hline Russia & 8 & 6262 & $1983-2010$ & 2015-2019 & 8 \\
\hline India & 6 & 3907 & 2002-2011 & 2015-2019 & 6 \\
\hline USA & 5 & 6320 & $1972-2013$ & 2016-2020 & 5 \\
\hline South & 4 & 5360 & 2008-2013 & 2016-2018 & 4 \\
\hline \multicolumn{6}{|l|}{ Korea } \\
\hline UAE & 3 & 4035 & 2012-2014 & 2017-2019 & 7 \\
\hline Belarus & 2 & 2218 & 2013-2014 & 2019-2020 & 7 \\
\hline Pakistan & 2 & 630 & 2011 & 2016-2017 & 2 \\
\hline Slovakia & 2 & 880 & 1985 & 2016-2017 & 2 \\
\hline Ukraine & 1 & 1900 & 1986-1987 & 2019 & 2 \\
\hline $\begin{array}{l}\text { Argentin } \\
\quad \text { a }\end{array}$ & 1 & 25 & 2014 & 2018 & 7 \\
\hline Brazil & 1 & 1245 & 2010 & 2018 & 1 \\
\hline Finland & 1 & 1600 & 2005 & 2018 & 1 \\
\hline France & 1 & 1600 & 2007 & 2017 & 1 \\
\hline Total & 62 & 59033 & $1972-2015$ & 2015-2021 & 47 \\
\hline
\end{tabular}

They were only two newcomer countries that have started the construction of their new first nuclear power plant by the year 2015. They were Belarus and United Arab Emirates, meanwhile Turkey reported has assigned commercially binding contracts. Bangladesh, Egypt, Jordan, Lithuania, Poland, Saudi Arabia and Vietnam have announced more or rather less concrete plans for new-build [5]. 2012 IAES analysis expected that Bangladesh, Belarus, Turkey, UAE and Vietnam to start building their first nuclear power plants and Saudi Arabia follows in 2013 [7].

\section{Commercial Power Plant in 1973}

Design Data and Safety Features of Commercial Nuclear Power Plants [8] report by December 1973 written by Fred A. Heddleson has listed few of the name of nuclear power plants existing at that time. They are:

$\begin{array}{ll}\text { - } & \text { Big Rock Point Nuclear Plant } \\ \text { - } & \text { Brown Ferry Nuclear Plant } \\ \text { - } & \text { Connecticut Yankee Atomic Power Plant } \\ \text { - } & \text { Diable Canyon Nuclear Power Plant } \\ \text { - } & \text { Dresden Nuclear Power Station } \\ \text { - } & \text { Fort Calhoun Station } \\ \text { - } & \text { Robert Emmett Ginna Nuclear Power } \\ \text { - } & \text { Humboldt Bay Power Plant } \\ & \text { Indian Point Nuclear Unit } 1\end{array}$




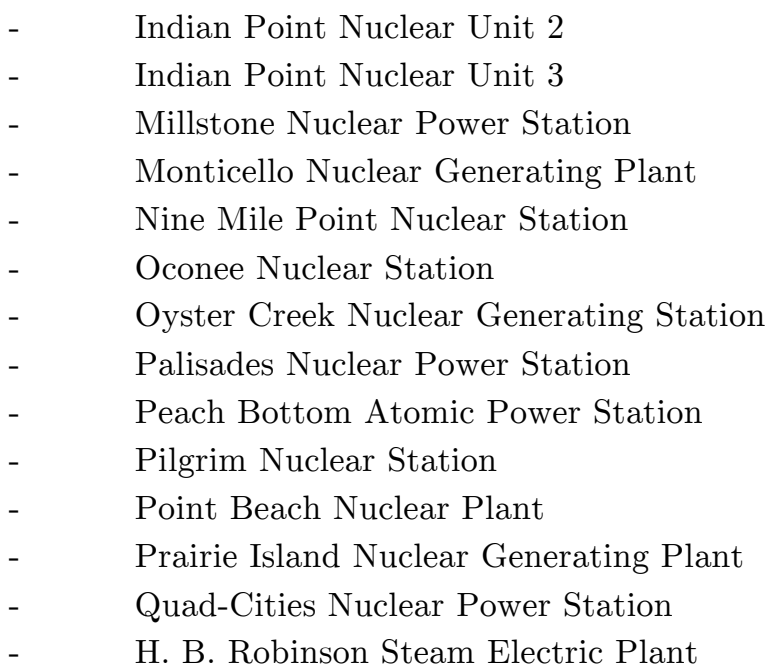

\section{Nuclear Energy in Africa}

Figure 2: Electrical Illumination on Earth as seen from Space, Comparison Africa with Other Continents

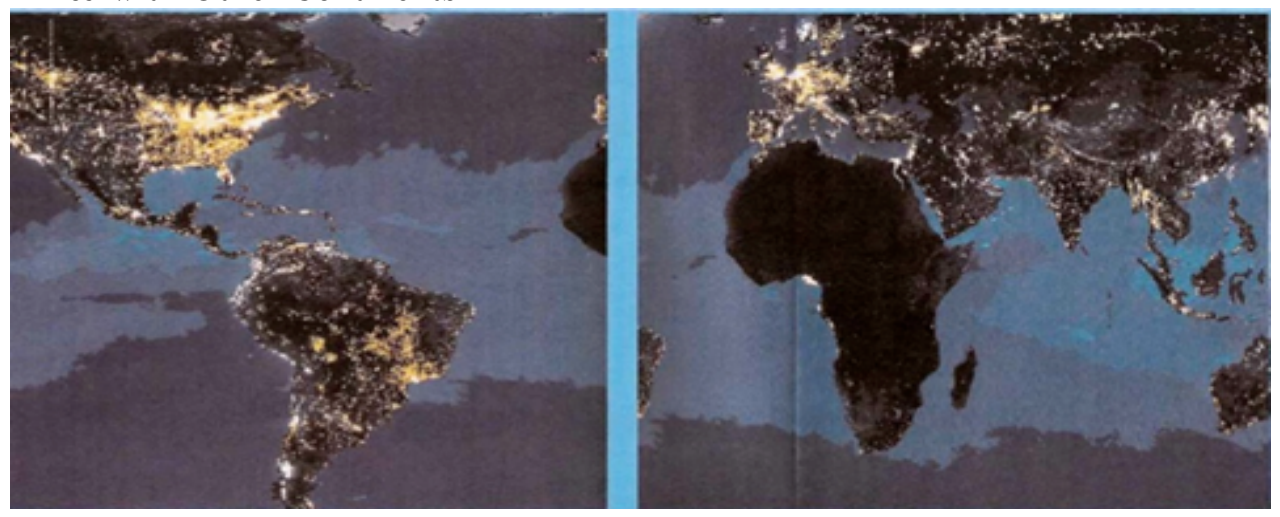

By the year 2015, Africa has reported to have one active nuclear power station at South Africa, a development of a 700MW nuclear plant in Ghana, research-oriented nuclear reactors in Kenya, Egypt, Ghana and the Democratic Republic of the Congo and growing of interest in nuclear power expertise in Namibia, Uganda, Nigeria, Senegal and Niger.

"Now we have rejuvenated the whole idea to go nuclear because it was envisaged that it would be so cheap that we would not even have to price electricity. We would write in our history books that once we used to ration power in this country. It will [also] spring new industries in steel technology, welding and various robotic roles. All these are spin offs from nuclear power."

By Robert Sogbadji, who's in charge of nuclear and alternative energy at Ghana's energy ministry [10]. As reported in 2014 World Nuclear Industry Status Report (WNISR), nuclear energy was used widely in 1996 at $17.6 \%$ and decreased to $10.8 \%$ in 2013 . That report concluded that the global nuclear industry was in decline and South Africa is the only country on the continent of Africa with a nuclear power station. The countries under review to build nuclear power station are Kenya, South Africa and Nigeria and analyses on those countries are ongoing. 
Ghana - a country that lies in the middle of the west coast of Africa. This country main source of electricity is hydro power. Until the year 2015, it accounts for $54 \%$ of the total installed capacity which is about $2186 \mathrm{MW} \mathrm{[11].} \mathrm{The}$ remaining percentage of source is supplied by thermal power plant which runs on natural gas and light crude oil. Due to draught, power supply from hydropower system and the expensive cost of crude oil on the international market to run the thermal power plant and delay of gas supply from Nigeria, both of the sources supplies are declining. To meet the long term energy needs, the Government of Ghana took a decision to explore the possibility of generating electricity from nuclear power [11].

\section{Nuclear Energy in Australia}

Professor Daniela Stehlik has carried out a study on an analysis of the formation of attitudes in Australia to new technologies, with nuclear power as the essential case since Australia is an unusual country where the government permits the mining and exporting of uranium but do not give out permits to use nuclear energy to generate electricity.

The result of the analyses of attitudes of the citizen of Australia are reported in Understanding the Formation of Attitudes to Nuclear Power in Australia written by Professor Daniela Stehlik and in a web site on the title of Nuclear Power for Australian Industry published by Australian Institute of Policy and Science.

Even though the government of Australia do not permit the usage of nuclear energy for electricity generating, Australia already a signatory of NonProliferation Treaty (NPT). By 28th April 2007, current federal government decided to adopt new uranium strategy where they increased the uranium exports and they prepared for the possible expansion of the nuclear industry in Australia, meanwhile, the Australian Labor Party (ALP) adopted the policy about allowing the mining and export of uranium on the basis of stated conditions [12]. But ALP remains to oppose the establishment of nuclear power plant and all other stages of the nuclear fuel cycle in Australia.

\section{Nuclear Power Plant in Antarctic}

The first reactor been built in Antarctica was PM-3A [13], a portable plant designated and built by Martin Co. The purpose of this reactor was to provide electrical power and to run a water-distillation plant. The reactor was set up at McMurdo Station; a barren spit of land selected by the United States since the reactor was belongs to United States. 
Figure 3: McMurdo Station at the Hunt Point Peninsular [13]

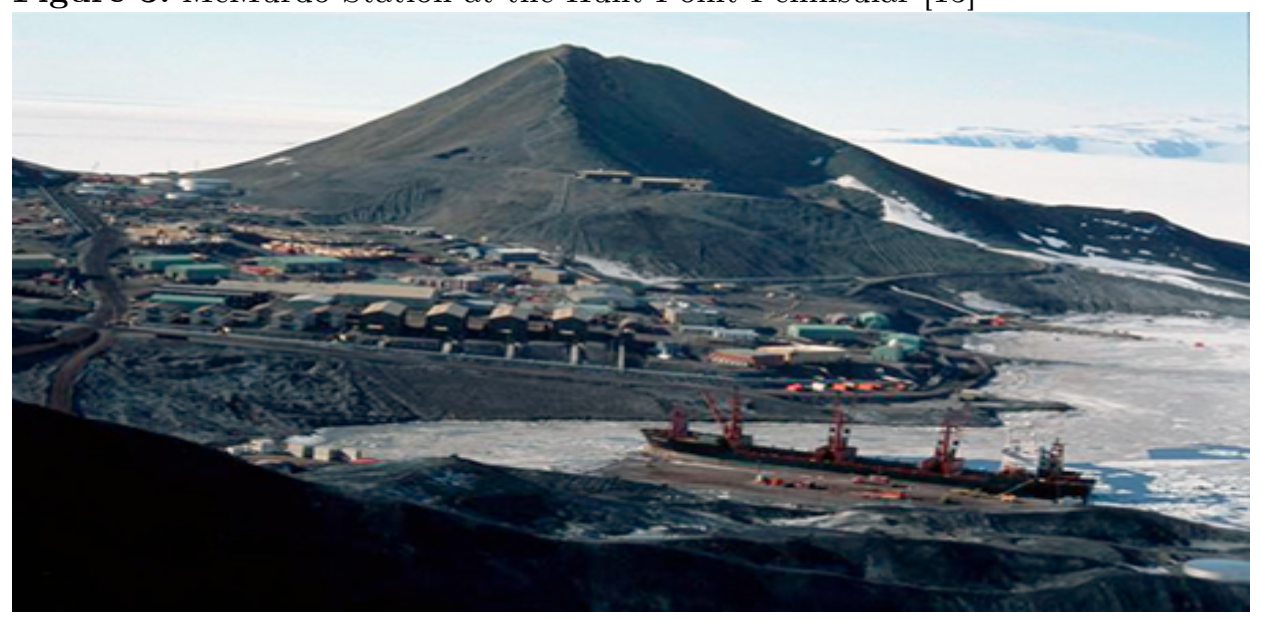

\section{Geographical Environment}

\section{Geology}

\section{Seismology}

In this section, the discussion will be focus on method of assessment of seismology effect on construction of nuclear reactor based on United Stated, Japan, Bulgaria, Swiss, South Africa and Korea. This method assessment is needed in order to make reactor can survive the environment. In United State, The Seismic Safety Margins Research Program (SSMRP) is a multiyear, multiphase program whose overall objective is to develop improving methods for seismic safety assessments of NPP using a probabilistic computational procedure. The program is being carried out at the Lawrence Livermore National Laboratory and it is sponsored by the US Nuclear Regulatory Commission, Office of Nuclear Regulatory Research [56]. Therefore, in designing nuclear reactor, the important factor is the structural integrity. Structural integrity is the first priority in the design of nuclear reactor internal structures. In particular, nuclear reactor internals should be designed to endure external forces, such as those due to earthquakes [47]. As example, Fukushima can be use as example in designing reactor as a safety precaution to be taken. A major earthquake off the Pacific coast of Japan, a tsunami disabled the power supply and cooling systems of three reactors of the Fukushima Daiichi power plant, causing a major nuclear accident. The accident triggered substantial releases of radioactive material and resulted in one of the worst nuclear disasters ever, second only to the Chernobyl disaster in 1986 [49]. In Europe region, Kozloduy NPP is the only nuclear power plant in operation in Bulgaria. It is located in the northwest part of the country, around $200 \mathrm{~km}$ from Sofia - the capital of Bulgaria, on the bank of the Danube River, near the town of Kozloduy. The territory of the Balkan Peninsula is characterized by active geodynamics [38]. The seismicity of the neighboring countries, like, Greece, former Yugoslavia and Romania (especially the Vrancea intermediate depth earthquakes), contributes to the seismic hazard in Bulgaria [52]. The seismic hazard for the territory of Bulgaria has been assessed on the 
basis of analyses of geological, geophysical, seismological studies and the results are presented in the many publications during the years [22]. It shows that Kozloduy NPP was built in area that far from active seismic activity area but the nearest area with NPP had $5.0<=\mathrm{M}<6.0$ it still can effect NPP. The structure of Kozloduy NPP must have the ability withstand some wave of earthquake from nearby area.

In Swiss, Probabilistic Seismic Hazard Analysis for Swiss Nuclear Power Plant Sites (PEGASOS) project was performed as a research project sponsored by the Swiss NPP utilities to improve the assessment of seismic risk in support of the plant-specific seismic PRAs. In this project, there are 4 subprojects; source characterization, ground motion characterization, site effect characterization and seismic hazard computation. To elaborate the way of all subproject by using logic tree methodology for quantification of seismic hazard [31]. One of analysis needed to be done is site amplification analysis to assess seismic activity. The goal of the amplification analysis is to develop the ground motion response spectra (GMRS) [14]. In South Africa, direct import approach had been used to get quantitative target performance for seismic design of NPP [42]. There are 6 methods in this approach:

- $\quad$ Seismic tectonic regions, regional and site geology characteristics

- Man-induced seismicity

- Range of nuclear installation technologies and SSCs represented in SPRAs

- $\quad$ Procedures used to develop probabilistic seismic hazard analyses

- Hazard slopes and design factors

- Spectral frequencies and qualitative performance criteria

The seismic probabilistic risk assessment (SPRA) is a tool to evaluate the actual safety considering the variability and the regulatory requirement for power plants under construction as well as in operation. In Korea, method for SFA is basically similar to that of EPRI called "response factor method". In this method, the response factor is a measure of conservatism included in seismic design and a ratio of design response to actual response. Korean method uses the multi-modes response spectrum shape factor to consider the effects of the more reasonable structural responses, while they only use the fundamental modal response in the EPRI method.

\section{Hydrology}

In this section, the discussion will be focus on method of assessment of hydrology effect on construction of nuclear reactor based on Belgium and Japan. This assessment will cover in water source for reactor, contamination of water to environment and safety feature against accident that cause by water. Water is one of important element in nuclear reactor that acts as coolant and moderator. Nuclear power plant usually placed near river or coastal areas. During siting process its importance to figure out source of water in to supply water to the nuclear power plant. The total water requirements of the plant depend on a number of factors, including the generation technology, generating capacity, the surrounding environmental and climatic conditions, and the plant's cooling system, which is the most important factor governing coolant flow rate [5]. The vast amounts of water are for cooling purposes typically through the use of a direct cooling or closed cycle cooling system. In a direct cooling system, the steam 
used to turn the turbines is cooled by water that is pumped through the condensers from an outside source and then discharged back into the environment. This differs from the closed cycle cooling system where the water used for cooling is pumped from the steam condenser to a cooling tower or pond and then recycled back to the condenser. While the direct cooling system has a relatively high amount of water usage from the environment, the closed cycle cooling system has higher amounts of water consumption due to losses from evaporation. [67] In both cases, the water usage and consumption for a conventional nuclear power plant is higher than for the average fossil fuel power plant (Table 1).

Table 2: Comparison of water requirements for fossil fuel and nuclear power plants

\begin{tabular}{|c|c|c|}
\hline $\begin{array}{c}\text { Plant and Cooling System } \\
\text { Type }\end{array}$ & $\begin{array}{c}\text { Water Usage } \\
\text { (gal/MWh) }\end{array}$ & $\begin{array}{c}\text { Typical Water } \\
\text { Consumption } \\
\text { (gal/MWh) }\end{array}$ \\
\hline $\begin{array}{c}\text { Fossil/biomass/waste-fueled } \\
\text { steam, once-through cooling }\end{array}$ & 20,000 to 50,000 & $\sim 300$ \\
\hline $\begin{array}{c}\text { Fossil/biomass/waste-fueled } \\
\text { steam, pond cooling }\end{array}$ & 300 to 600 & $380-480$ \\
\hline $\begin{array}{c}\text { Fossil/biomass/waste-fueled } \\
\text { steam, cooling towers }\end{array}$ & 500 to 600 & $\sim 480$ \\
\hline $\begin{array}{c}\text { Nuclear steam, once-through } \\
\text { cooling }\end{array}$ & 25,000 to 60,000 & $\sim 400$ \\
\hline Nuclear steam, pond cooling & 500 to 1100 & $400-720$ \\
\hline Nuclear steam, cooling towers & 800 to 1100 & $\sim 720$ \\
\hline
\end{tabular}

Nuclear power plants require more cooling water because they operate at thermodynamically lower steam conditions which results in a lower cycle efficiency. Thus a greater steam recirculation rate which contributes to a greater flow of cooling water is needed to produce a given amount of electricity compared to an average fossil fuel plant. [68]. In Belgium, Doel and Tihange routinely discharge radionuclides into the terrestrial and aquatic environments. The annual limits for discharges and emissions are specified by the Federal Agency of Nuclear Control (FANC), which is the National authority responsible for supervision of discharges, in such a way that the resulting doses to the population must not exceed $1 \mathrm{mSv}$ per year for all pathways combined. For the liquid discharge limits set to protect man, all RQs calculated in the present study are below unity. Actual discharges are up to 4 orders of magnitude lower than discharge limits, resulting in even lower RQs. It is concluded that the liquid radiological discharge limits for the Belgian NPP are stringent enough to not harm the aquatic and terrestrial environment of the Meuse and Scheldt [60]. Nuclear power plants along rivers have to be protected against flooding due to precipitation and other events such as failure of water controlling structures such as dam collapse. Plants along the coast have to be protected against surges, tsunamis, and wind induced waves. The issue of flooding has caught world-wide attention due to the Fukushima accident in March, 2011, when a $14 \mathrm{~m}$ tsunami wave swept through a nuclear plant site in Fukushima in Japan destroying emergency generators and pumps 
[16]. When the tsunami waves reach the coastal zone, they produce hazardous effects, such as an extreme change of water level, inundation, strong current velocities, hydro-dynamic forces to barrier structures, scour, and debris flow [7]. Probabilistic tsunami hazard analysis (PTHA) helped better understanding effect tsunami on structure of NPP and can evaluate quantitatively.

\section{Country Requirement}

Most countries with long histories wish to preserve sites and structures having particular historical or cultural significance. As for example, the Wolsong site in Korea that locate four CANDU units in operation or under construction. The site was moved to a few kilometers from the originally selected site because of an underwater tomb of an ancient king. [27]. Other factor that related to country requirement is international borders. Since a potential accident in a NPP can lead to consequences of radioactive releases for many kilometers, a site near an international border raises the problem of appropriate treaties with the neighboring country. It seems prudent not to site a NPP close to an international border since inter-country relations can change even if there is agreement. There is an international treaty on the notification of neighboring countries in the event of an accident. A few countries that has their own requirement in siting of NPP can be made as an example like Finland, United Kingdom (UK), United States of America (USA), Australia, South Africa, Brazil and Vietnam.

Finland is a small country with a central government. It has two utilities with NPP where one of which is privately owned and the other is state owned. There is a central nuclear regulatory body called the Finnish Centre for Radiation and Nuclear Safety (STUK) which will report to the Minister for Social Affairs and Health. The overall licensing authority is the Council of State which is the senior governing body. For site approval, a proposed site in Finland is part of the first formal stage of licensing of a nuclear facility which is decision in principle. The applicant must submit a description of the proposed site and the analysis of environmental effect. Then, they need to submit the plans for preventing or mitigating all effects and the general description of plans for management of spent nuclear fuel and radioactive waste. As an addition, the submission must include the competence of the applicant, description of applicant's financial resources and the economic viability of the project and a description of the proposed plant. STUK has identified three zones. The first zone is the site of the power plant and it extends to approximately 1kilometre from the facility. Within this area, permanent settlement is prohibited and the operator of the facility should have authority over all activities carried out in the area. The area can include a public road but only if the volume of traffic is small and the traffic can be diverted elsewhere in an emergency. The second zone which known as a protective zone extends to approximately 5kilometres from the facility. Development is restricted in this zone to exclude sensitive activities like hospitals and schools. The third zone which is the emergency planning zone extends to about 20kilometres from the facility. Plans are required to be prepared for this area to ensure the evacuation of people in an emergency case.

For the United States of America (USA), it is a federal country but the authority over nuclear matters rests with the federal government. The central regulatory agency is the United States Nuclear Regulatory Commission (USNRC). Most of the utilities are privately owned, several nuclear vendors or 
designers and several architect or engineers which will handle the rest of the plant. The major legislation is the Atomic Energy Act which was originally passed in 1954 and the Energy Reorganization Act of 1974 which abolished the Atomic Energy Commission (USAEC) which then created the USNRC. Other laws also apply, most importantly the National Environmental Policy Act. The rules for the licensing process for nuclear installations are spelled out in regulations: Title 10, Code of Federal Regulations (CFR), Chapter 1 - Nuclear Regulatory Commission (10 CFR 1). There are two major steps involved: Construction License and Operating License. An Early Site Permit or can be called as Limited Work Authorization (LWA) may be issued prior to a Construction License to allow for site preparation work. The law is according to 10 CFR 2. Whereas, the criteria for siting for nuclear reactors are set-out in regulations 10 CFR Part 100. The large staff of the USNRC, the Advisory Committee on Reactor Safeguards (ACRS) and also if appropriate, the Advisory Committee on nuclear waste will review the submitted information. Construction License can be issued after a public hearing is done. A three-member Atomic Safety and Licensing Board appointed by the five-member Commission will conduct the hearing formally. An environmental assessment is required which is reviewed by the Environmental Protection Agency (EPA) and the state concerned, as well as by the USNRC.

In Australia, half of the population opposes nuclear energy and two thirds say they would oppose a nuclear power plant in their local area. Given this, in order for there to be a thorough and full-blooded debate about nuclear energy, it is necessary to identify the sites that are best suited to nuclear power plants. There are four primary criteria for the siting of nuclear power plants in Australia: proximity to appropriate existing electricity infrastructure; proximity to major load centers where they require high demand of electricity; proximity to transport infrastructure to facilitate the movement of nuclear fuel, waste and other relevant materials; and access to large quantities of water for cooling. Data prepared by the Australian Bureau of Agricultural and Resource Economics suggest the overwhelming majority of the increase in generation capacity is likely to occur in the eastern states. Given this, it is likely that most of the 12 NPP would be located on or near the National Electricity Market (NEM) [28]. As the report of the Nuclear Taskforce indicates, the sites could be located near existing coal-fired generators on the NEM to take advantage of electricity infrastructure and grid connections. In order to minimize transmission losses, NPP would preferably be located near major centers of demand. This would ensure more efficient delivery of electricity and the most important thing is to reduce financial costs. The major load centers are the capital cities and large regional centers, particularly those that have energy-intensive industries. Due to these factors, it is likely that they would be reliant on imported fuel rods and they may also export spent fuel rods for reprocessing. To reduce financial costs and facilitate the import and export of nuclear fuel and waste, NPP would preferably be located near suitable transport infrastructure like ports, roads and railway lines. Other than that, NPP would preferably be located in coastal areas to ensure access to seawater.

The Koeberg Nuclear Power Station (KNPS) is owned and operated by Eskom, which reports to the Minister of Public Enterprises. The Department of Energy (DoE) plays a leading governance role in nuclear technology and safety. The Minister of Energy is the executive authority responsible for overseeing the 
Nuclear Energy Corporation of South Africa (NECSA) and the National Nuclear Regulator (NNR). NECSA undertakes and promotes research and development in the fields of nuclear energy, radiation sciences and technology, medical-isotope manufacturing, nuclear liabilities management, waste management and decommissioning. To implement a decision-making phase approach to the nuclear program, cabinet approved the establishment of the National Nuclear Energy Executive Coordination Committee (NNEECC). The Integrated Nuclear Infrastructure Readiness (INIR) review was conducted in South Africa between 30 January and 8 February 2013 where the process involved all industry key role players [29]. South Africa is the first country that will have nuclear program to assess its readiness for expansion. INIR process is not legally binding but assists the country to benchmark with other countries. The IAEA has developed an INIR report with recommendations and once the report is finalized, it will be made public. Eskom appointed an independent consultant, Arcus Gibb to undertake an Environmental Impact Assessment (EIA) for the proposed construction of a nuclear power station (Nuclear-1) and associated infrastructure. The application is for a NPP, with a maximum nominal capacity of $4000 \mathrm{MW}$ and five sites were selected and evaluated during the scoping phase. They are Brazil and Schulpfontein in the Northern Cape, Bantamsklip in the Western Cape, Duynefontein in the Western Cape and Thyspunt in the Eastern Cape. Three sites were taken forward into the EIA phase where 28 specialist studies have been completed. In addition to the EIA, there are a number of steps that are required prior to a new nuclear power station being constructed in South Africa. Negotiations must be undertaken with the suppliers of nuclear power stations, a safety report for the specific design must be submitted to the National Nuclear Regulator for evaluation and approval and a Nuclear Installation License obtained and a generating license must be obtained from the National Energy Regulator of SA (NERSA) [29]. There also have numerous other permits and authorizations such as water use licenses, zoning applications and domestic waste permits that are required for any not only nuclear power generating project to proceed.

For Brazil, the basic legislation governing this policy is the Brazilian Constitution. It stated that all the nuclear energy activities shall be solely carried out for peaceful uses and always under the approval of the National Congress. Recent law on 20th November 2001 established rules for the siting, licensing operation and regulation of radioactive waste facilities in Brazil. The constitutional principles regarding protection of the environment require that any installation which may cause significant environmental impact to environment should be made public. For nuclear facilities, the Federal Constitution provides that law shall approve the siting of the installation. Therefore, licensing of nuclear installations subject to both a nuclear license by Brazilian National Commission for Nuclear Energy (CNEN) and an environmental license by the Instituto Brasileiro do Meio Ambiente e dos Recursos Naturais Renováveis (Brazilian Institute for the Environment and Renewable Natural Resources IBAMA), with the participation of state and local environmental agencies as stated in the National Environmental Policy Act [30]. These principles were established by the Federal Constitution of 1988 when Angra 1 had already been in operation and Angra 2 was already under construction [30]. Therefore, licensing of these power plants followed a little bit different in procedures aspect. 
The law recognizes 3 types of deposits. The first one is initial and operated by the waste generator where intermediate and final which also called repository. Law establishes the rules for site selection, construction and operation. For the licensing and control, it is deposit by CNEN. Therefore, all the requirements established in the Brazilian legislation must be fulfilled in order to obtain and maintain the corresponding licenses and the operating organization.

In order to carry out the licensing review of NPP in Korea, the Advisory Committee on Reactor Safety (ACRS) was established in 1972 with 15 experts in various nuclear related fields. They are located under the Atomic Energy Commission of the Ministry of Science and Technology (MOST). NSC launched a series of development program to establish the regulatory criteria applicable to the design, construction, testing, inspection and operation of the reactor in Korea. However, the majority of important codes and standards applicable in the vendor countries (U.S. and France) were still applied to the licensing of these plants together with some appropriate modifications. The audit calculations were actively performed at the NSC as part of independent assessment of major safety analysis results described in the preliminary safety analysis report (PSAR) and in final safety analysis report (FSAR). In the application of licenses for NPP construction and later for operation, the licensee should submit to the MOST various documents demonstrating the adequacy of the proposed NPP design, in conformity with the Atomic Energy Laws. Then, Korea Institute of Nuclear Safety (KINS) has to perform a detailed review and assessment of the technical submissions to determine whether the design complies with the specified safety requirements for siting, construction and operation of the proposed nuclear installations.

The licensing procedure consists of two steps, Construction Permit (CP) and Operating License (OL). The review objectives of $\mathrm{CP}$ are to confirm the safety of the proposed NPP design, which should meet the related regulatory codes and standards and to review the safety of the preliminary designs which include the principles and concepts of the plants design and the implementation of the regulatory criteria and also to evaluate the environmental impact and the strategy for minimizing its effects. Site Survey Report and Detailed Geological Survey Report are also required for the application of Early Site Approval and Limited Work Authorization before the construction permit. As the standardization and the development of next generation reactor, the establishment of industrial codes and standards applicable to Korean NPP are making progress, the licensing system in Korea is expected to be stabilized.

\section{Public acceptance}

As a type of green energy, nuclear energy is being promoted in many countries around the world, and it has become one of the alternatives solutions to reducing the greenhouse effect and pollution. Development of nuclear power plant has not always been a smooth process around the world as public acceptance becomes a hitch. Recent accident such as Fukushima-Daiichi nuclear accidents change the public perception of nuclear energy in a way that the nuclear power plant can explode even with sophisticated technology. Public acceptance in site selection is not much different with acceptance of nuclear energy. Without public acceptance on nuclear power, the authorities cannot plan on site selection. Thus, in preparing the site for nuclear reactor, public trust must be gained to avoid 
unrelated event such as the anti-nuclear movement demonstration. Government can conduct survey or opinion poll to investigate the awareness of public about nuclear. The data then can be process to see if the public understand what authorities are going to development. In case the data shown are not satisfied, several steps can be taken to gain public acceptance in nuclear power such as advertising or using internet to spread news about nuclear power.

Countries in Asia greatly affected by the Fukushima accident, as for China, public acceptance has changes since the accident which led to Chinese citizen to purchase salt belief that iodine is effective against effects of radiation [32]. Public acceptance of nuclear in China is a sensitive issue compare to planning stage of nuclear power plant. Citizen of China protest to re-initiated the nuclear power plant in 2013 after 2 years' hiatus. July 12, 2013, within the announcement period of the China National Nuclear Cooperation (CNNC) Longwan Industrial Park Project Social Stability Risk Assessment, public protests in resistance against the local construction of nuclear fuel factory and government eventually cancelled the project [32]. Meanwhile in other part of China, the public willingness to pay to avoid having clear power plant. Due to same accident, the public acceptance of nuclear energy decline sharply and the share of nuclear power in electricity generation decreased from $16.8 \%$ in 2011 to $13.5 \%$ in 2012 [33]. The acceptance of nuclear energy is different in Japan, the public approved in necessity of nuclear power plant according to surveyed by Prime Minister's Office in Japan on Sep. 1990. $48.5 \%$ approve that nuclear power plant should be increased, $30.2 \%$ should not be increased more, $8.9 \%$ should be decreased from new, $9.8 \%$ have no opinion and the rest vote for in-service plants should be stopped [34].

Australia is largest known country for uranium resources, almost one-third of world total but third ranking producer behind Kazakhstan and Canada [35]. Even with many resource of uranium, Australia does not consent about nuclear power because of extensive low cost coal and natural gas. Another reason Australia does not have nuclear power is the anti-nuclear movement at Australia that been actively become a hitch in nuclear planning. Anti-nuclear movement of Australia such as Anti-Nuclear Alliance of Western Australia or Australian Conservation Foundation had been actively held public debate about nuclear in Australia. McNair Gallup poll from Australian Data Archive (ADA) showed that during 1979 Australian oppose the construction on nuclear power station by $56 \%$ margin compare to $34 \%$ who approved and $10 \%$ answered "don't know" [36]. This survey was conducted after the Three Mile Island accident. The survey conduct also by McNair on 2007 with same question "Do you favor or oppose the construction of nuclear power stations in Australia?" show that public who oppose was a lot compare who is approved by $53 \%$ to $41 \%$ respectively while $6 \%$ were other votes. During 2009, the survey conducted again and the result was different compare to 1979 and 2009. Although the result was not different by large margin, people who favored construction on nuclear power station was $49 \%$ compare to people who oppose $43 \%$ and $8 \%$ others. The survey data was collected and documented by Australian National University (ANU) and archived at Australian Data Archive (ADA)

Antarctica is one of the isolated continents in the world. The resource of energy and food always become hard to transfer in and out of the region. United States Congress has authorized the design and construction of nuclear reactor on [37]. McMurdo Station located at Antarctica and generates electricity by PM-3A 
portable reactor. PM-3A was meant to be transported by LC-130 aircraft because the accessible to Antarctica is easier in this way rather than using the ship. McMurdo Station was built to fulfil the aim which is to overcome the difficulties associated with supplying the large fuel demands required for operations. [38]. McMurdo Station also responsible to supply electric heating to replace the fire hazards associated with oil-fired heating units [38]. Antarctic nuclear power does not relate to any public interest because the reactor build is under decision of United States Congress. Furthermore, Antarctic population is not many to even consider its public interest in nuclear power.

After violent introduction of nuclear by first atomic bomb during 1945, the public reaction for nuclear has becoming worse. People always take nuclear as a dangerous weapon and tool of destruction. After the Three Mile Island and Chernobyl, the news about nuclear become deteriorated for public. Nuclear actually is safe as many facts stated, in fact, nuclear will become replacement of current energy supplement in near future. Public concern on nuclear power greatly increased due to fossil fuels had lessened. Africa known for gold mining for their economy and same for other countries, Africa tend to demand high energy power for the industries. Koeberg power station is the only nuclear power station in South Africa and entire Africa continent. Located $30 \mathrm{~km}$ away from Cape Town and owned by Eskom, national electricity supplier. Koeberg Alert is an anti-nuclear movement mainly focuses on construction of Koeberg power station. Public acceptance in South Africa is influence by the event of incidents happen during the past and mostly the bitter truth about nuclear technology. The bombs dropped at Nagasaki and Hiroshima influenced public acceptance of nuclear power greatly. Despite education, the general public finds it difficult to separate the horror images of these bombs, from the peaceful use of nuclear energy and the accidents at Three Mile Island and Chernobyl are well known and most opponents to nuclear power will cite these examples when arguing against nuclear power [39]. The government of South Africa proposes several ways to answer public fear and gain trust at the same time such as power station visits. Power station visits focus on university groups, industrial groups, or others for who is considered to be effective and other ways including visitors' center, advertising and usage of internet [39]. The initiative of this plan will gain trust and acceptance from public and shown the good image of nuclear technology.

Public acceptance in Europe is different according to each country. Before Fukushima-Daiichi accident, public acceptance in nuclear power in Europe was higher compared to after the nuclear accident. This proves that event changes people perception by visual. Greater demand of energy making Europe is the largest energy importer in the world, importing $53 \%$ of its energy, at an annual cost of around $€ 400$ billion [40]. Increasing concerns about climate change, nuclear power become one of the solutions to overcome this. According to Eurobarometer survey, nearly identical shares of respondents' express support for nuclear energy (44\%) and opposition to it (45\%) and others answer "Don't Know" [41]. However, citizens in the countries that have nuclear power tend to favor the nuclear energy compared to countries which do not gave nuclear power. The strongest support is found in the Czech Republic and Lithuania but also in Hungary, Bulgaria, Sweden, Finland and Slovakia six in ten respondents or more are in favor of energy production by nuclear power stations [41]. France is world's largest power generator on a per capita basis and ranks second in total installed 
nuclear capacity behind United States [42]. Public support for nuclear power in France always been strong and France make a right choice during 1970s to choose nuclear to reduce energy dependency. Now, France has 58 commercial power plant and to maintain the public trust, France also conduct the visiting to nuclear power plant for school and industry to expose them the nuclear power as an energy rather than a weapon of destruction. Although nuclear reactors have been operated safely, the French still worry the risky of nuclear. About $55 \%$ think the risk of accidents is high [42]. However, French trust their authorities and regulators with controlling and ensuring the safe operation of nuclear reactors.

As for United Kingdom, oil reserves are dwindling and until a minimal upturn in 2015, output had been declining [42]. Oil prices increasing and UK see this as a threat to energy supply. With heavy industries in UK, the demands for more energy keep increasing until UK decide to find alternatives to overcome this. People see nuclear power is a means to addressing this issue. The public debate about energy helped nuclear power gain trust in the public. Furthermore, UK citizens also concerns about environmental issue and climate change which mostly cause by other energy supply such as fossil fuel. They were aware that renewables energy alone cannot tackle the energy demand and environmental issues. Despite having eight nuclear reactors operated and supply $14 \%$ of total electricity in 2015, Germany having a phase-out on nuclear power by 2022 [42]. After the accidents on Fukushima-Daiichi, on August 2011, Germany shut down its eight reactors permanently. With all commotion happen, on April 2014, Geman Atomic Forum (DAtF) conducted an opinion poll on unified European energy policy with $72 \%$ support it [42]. $56 \%$ oppose the idea that Germany should review key energy policy such as the nuclear phase-out [42].

With dropped price in gas over past year, the public concern about nuclear energy is dropping with $54 \%$ oppose nuclear energy [43]. According to Gallup website, people who favor nuclear energy is $44 \%$ and it is for the first times people oppose is many compare to favor [43]. America with 99 operating reactors, 34 boiling water reactor (BWR) and 65 pressurized water reactor (PWR) show that the demand of energy is not part of the problem but the public acceptance currently in opposing the nuclear energy. The reason behind this is the dropped in gas price. This seems to have lessened Americans' perceptions that energy sources such as nuclear power are needed [43]. The result of opposing also does not come from fear because the last accident related to nuclear way back during 2011.

Public acceptance is different for each country because it is depending on requirement or the objectives of development nuclear reactor. Some country favor nuclear power as dependable energy and some country see nuclear power as destruction. People live near nuclear reactor seem to favor nuclear energy as they have witness first-hand the capability of nuclear power. The opposition called themselves anti-nuclear movement and spread the negativity of nuclear power by public debate or advertising. The anti-nuclear movements always tend to target the accidents happen in the past as their modal to spread the awareness. To study public acceptance on nuclear power is complicated and as well as there is no ends to it. The authorities should take responsibility in spread the awareness to public. 


\section{Nuclear Power Plant Site Evaluation in Malaysia}

The Malaysia Nuclear Power Corporation (MNPC) was established in 2011 as the Nuclear Energy Program Implementation Organization (NEPIO) based on the IAEA guidelines. The MNPC will focus on critical enablers as identified in the ETP, including public acceptance of the project and the readiness of the correct regulatory framework in Malaysia. MNPC play a big role to provide critical consideration on site configuration and as first mover on developing Nuclear Power Plant (NPP) station in Malaysia.

Previous researcher work on site evaluation in Peninsular Malaysia, several harmful activities, natural disaster that might be happen during operation and NPP construction were found such as, earth-quake. Ground movement and surface stability is important to evaluate external events and possible hazard related to seismological and geological condition. Hence, geological and seismological condition in the area must be considered during selection. IAEA stated two important events related to geological and seismological features earthquakes and surface faulting. Peninsular Malaysia has low possibility of earthquake event since it did not lie on the Pacific Ring of Fire. However, Malaysia did felt the effect of high magnitude earthquake occurred in the neighboring country like Indonesia. Malaysian Meteorological Department has recorded felt earthquake events and intensity in Johor.

Table 3: Certain target area for site evaluation consideration that are being analysis

\begin{tabular}{|c|c|c|c|c|}
\hline No. & Date & Location & $\begin{array}{c}\text { Magnitude } \\
\text { (Ritcher } \\
\text { Scale) }\end{array}$ & Intensity \\
\hline 1 & 1 October 2019 & Southern Sumatera & 6.2 & IV \\
\hline 2 & 16 August 2009 & Southern Sumatera & 6.5 & IV \\
\hline 3 & 25 February 2008 & Southern Sumatera & 6.1 & IV \\
\hline 4 & 4 January 2008 & Southern Sumatera & 6.5 & II \\
\hline 5 & 13 September 2007 & Southern Sumatera & 6.1 & IV \\
\hline 6 & 12 September 2007 & Southern Sumatera & 6.4 & IV \\
\hline 7 & 6 March 2007 & Southern Sumatera & 5.8 & IV \\
\hline
\end{tabular}

Table 2 shows the statistic reading due to earthquake near Johor Peninsular Malaysia. This earthquake occurs in nearest country mostly Indonesia that could give several amounts of scale reading.

Johor were chosen to be one of the site selection targets in Malaysia due to Geo-structure feasible. Surface faulting can occur from natural geological and seismological features or human activity that may lead to surface change or movement. In site selection, area with minimum likelihood of surface faulting and earthquake are most preferred. Sites with competent bedrock generally have suitable foundation conditions. Otherwise, area with stable rocks and solid soils such as dense sands and glacial tills are considered suitable.

NPP installation in Malaysia needed to be considered properly with code and condition as aspect to be enhance to reduce effect on environmental hazard. This operation of nuclear power plant may lead to hazardous event that are influence 
by natural disaster or radiological risk that are depend on the radiological study on that particular country. Since, Malaysia had been through a lot of research on environmental impact assessment throughout Malaysia region and it shows positive feedback for nuclear Power Plant siting to be performed. A lot of positive benefit that can be provide to Malaysia citizen which is energy supply for personal home hospitality in low cost and energy generation rate will also increases. NPP operation will be supervise in controlled area that has been establish by IAEA Standard and code for ensuring the unwanted event to initiated. Safety is prior aspect for nuclear installment for environmental friendly used toward individual, society and environmental.

\section{Conclusion}

In conclusion, the siting of power plant is likely to be one of the most politically contentious issues if the government decided to promote the establishment of a NPP. There is a considerable amount of community opposition to the nuclear industry and siting issues are often a source of significant conflict even the countries that rely on nuclear power for a large proportion of their electricity needs. On the other perspective, safety assessment in licensing process is complicated and unfamiliar in most of the countries which need to be performed by high quality experts along with the international consultants for supporting safety assessment for an appropriate approach. It is important for licensing process, infrastructure, legal development and human development. There are still many things that we need to consider in the coming future even the current achievement gained recently is quite impressive. The critical aspect is to inform the public about nuclear energy and nuclear power besides gaining the support from the. Any new system should be designed according to sustainability principles where it will include the precautionary principle. To implement the requirement, a comprehensive framework of sustainability principles, indicators and criteria should be developed to the point where it could be used to assess the sustainability of any proposed engineered system. Lastly, further research would need to be carried out before it could be concluded that the areas are definitely suitable for NPP construction.

\section{References}

GUIDELINE FOR SITE SELECTION FOR NUCLEAR POWER PLANT. (22 Mac 2011). Dengkil, Selangor: Atomic Energy Licencing Board.

M. E. Foster, G. M. (December 1982). History of the PM-3A Nuclear Power Plant McMurdo Station, Antarctica. Washington: NAVAL ENERGY AND ENVIRONMENTAL SUPPORT ACTIVITY.

Caubit, D. A. (2005). Brazilian Nuclear Energy Commission.

Nobel Lectures, Physics 1901-1921. (1967). Amsterdam: Elsevier Publishing Company.

Agency, I. A. (2003, November 17). Nuclear Power Plants Information: Operational \& Under Construction Reactors by Country. Retrieved from http://www.iaea.org/cgibin/db.page.pl/pris.reaopucct.htm.

Schneider, M. (19 March 2015). The Global Outlook of Nuclear Power and the French Case. Austrian Energy Agency \& Federal Ministry of Agriculture, Forestry, Environment and Water Management. Vienna. 
Bodansky, D. (1996). NUCLEAR ENERGY: Principles, Practices and Prospect. New York: SpringerVerlag New York

Heddleson, F. A. (December 1973). DESIGN DATA AND SAFETY FEAUTURES OF COMMERCIAL NUCLEAR POWER PLANTS. Oak Ridge, Tennessee: OAK RIDGE NATIONAL LABORATORY.

F. Erepamo Osaisai, C. E. (30-31 May 2011). Nuclear Power Introduction in Nigeria: Organization and Way Forward. Second Regional Conference on Energy and Nuclear Power in Africa. Cape Town.

Brenda Martin, D. F. (27 July 2015). Final Report - Findings of the African Nuclear Study. Southern Africa: Heinrich Böll Foundation.

Basu, P. C., Ravindra, M. K., \& Mihara, Y. Component fragility for use in PSA of nuclear power plant. Nuclear Engineering and Design. doi:http://doi.org/10.1016/j.nucengdes.2016.10.018

Kidd, S. (2014, October 6). Retrieved June 7, 2015, from http://www.neimagazine.com/opinion/opinionthe-world-nuclear-industry-is-it-in-terminal-decline$4394815 /$.

Long, T. (2011, April 3). MARCH 4, 1962: NUCLEAR AGE COMES TO ANTARCTICA. Retrieved from WIRED: https://www.wired.com/2011/03/0304antarctic-nuclear-plant-mcmurdo-sound/

Francois, W., David, A., Serge, A., József, B., Raffaello, D. F., N.H., D., . . . Peter, W. (1990). Nuclear. Survey of Different Approaches Utilised to Aid Public Acceptance of Nuclear Energy, 38.

Park, J.-B., Choi, Y., Lee, S.-J., Park, N.-C., Park, K.-S., Park, Y.-P., \& Park, C.-I. (2014). MODAL CHARACTERISTIC ANALYSIS OF THE APR1400 NUCLEAR REACTOR

INTERNALS FOR SEISMIC ANALYSIS. Nuclear Engineering and Technology, 46(5), 689-698. doi:http://doi.org/10.5516/NET.09.2014.017

H. J. Laue, L. L. (n.d.). Nuclear Power in Developing Countries.

Nations Online, Political map of Ghana. (n.d.). Retrieved from http://www.nationsonline.org/oneworld/map/ghana_map.htm.

Simeonova, S., Solakov, D., Leydecker, G., Busche, H., Schmitt, T., \& Kaiser, D. (2006). Probabilistic seismic hazard map for Bulgaria as a basis for a new building code. Natural Hazards and Earth System Sciences, 6(6), 881-887.

Foratom. (2017). Energy Policy, Economy and Law. What People Really Think about Nuclear Energy, 2.

Klügel, J. U. (2005). Problems in the application of the SSHAC probability method for assessing earthquake hazards at Swiss nuclear power plants. Engineering Geology, 78(3-4), 285-307. doi:http://doi.org/10.1016/j.enggeo.2005.01.007

Smith, P., Dong, R., Bernreuter, D., Bohn, M., Chuang, T., Cummings, G., Wells, J. (1981). Seismic Safety Margins Research Program. Phase I, final report-overview. Retrieved from

Nhleko, S. (2013). Application of the performance-goal based approach for establishing the SSE site specific response spectrum for new nuclear power plants in South Africa. Nuclear Engineering and Design, 255, 287-295. doi:http://doi.org/10.1016/j.nucengdes.2012.10.023

Myle Scheider, A. F. (July, 2015). The World Nuclear Industry Status Report 2015. Paris, London: The Green Political Foundation.

Ministry of Energy of Lithuania, "Working Group's Conclusions for Preparation of Proposals Regarding Cost-Effective and Consumers-Favorable Self-Provision with Powet and Other Energy Resources". (2013, April 25). Retrieved June 7, 2015, from http://www.enmin.lt/lt/naujienos/Conclusions_of_the_Working_Group2.pdf.

Rehdanz, K., Welsch, H., Narita, D., \& Okubo, T. (2015). Well-being effects of a major natural disaster: The case of Fukushima. Journal of Economic Behavior \& Organization, 116, 500-517. doi:http://dx.doi.org/10.1016/j.jebo.2015.05.014

Hixson, L. W. (2012, February 24). Enformable.com. Retrieved May 5, 2015, from http://enformable.com/2012/02/oaea-vietnam-and-4-other-countries-to-incorporate-nuclearenergy-after-fukushima/.

Isaac Ennison, T. A. (2012). Determination of Suitable Sites for Nuclear Power Plants in Ghana: The Issues Involved.

Macintosh, A. (2007). Siting Nuclear Power Plants in Australia. Research Paper No. 40.

Commission, U. N. R. (2007). A performance-based approach to define the site-specific earthquake ground motion. Regulatory Guide, 1, 24.

Australian Labor Party, "National Platform and Constitution". (2007). Retrieved from www.alp.org.au/download/now/2007_national_platform.pdf [hereinafter National Platform].

Stott, A. K. (2013). The current status of nuclear energy in South Africa.

Guo, Y., \& Ren, T. (2017). Energy Policy. When it is unfamiliar to me: Local acceptance of planned nuclear power plant in China in the post-fukushima era. 
Stehlik, P. D. (April 2010). UNDERSTANDING THE FORMATION OF ATTITUDES TO NUCLEAR POWER IN AUSTRALIA. Melbourne Victoria, Australia: National Academies Forum (NAF).

World Nuclear Association. (2017, January). Australia's Uranium. Retrieved from World Nuclear Association: http://www.world-nuclear.org/information-library/country-profiles/countries-af/australia.aspx

Boyd, F. (1997). Siting of Nuclear Power Plants.

Blaufox, M. D. (1988). Radioactive artifacts: Historical sources of modern radium contamination. Seminars in Nuclear Medicine, 18(1), 46-64. doi:http://dx.doi.org/10.1016/S0001-2998(88)800199

Reid, T. (2014). Nuclear Power at McMurdo Station, Antarctica.

Eurobarometer. (2008). Special Eurobarometer 297. Attitudes Towards Radioactive Waste, 5.

Koyama, S. (2013, September). Nippon Export and Investment Insurance. Retrieved July 14, 2014, from http://www.oecdnea-nea.org/ndd/workshops/wpne/presentations/docs/3 1 KOYAMA 2013 0919 OECD Seminer.pdf.

V. V. Kulik, D. M. (2011, August 9). Letter to the European Commission.

Milev, G., \& Vassileva, K. (2007). Geodynamics of the Balkan Peninsula and Bulgaria. Paper presented at the International Symposium on Strong Vrancea Earthquakes and Risk Mitigation.

Groudev, P., \& Petrova, P. (2017). Overview of the available information concerning seismic hazard for the Kozloduy NPP site. Progress in Nuclear Energy, 97, 162-169. doi:http://doi.org/10.1016/j.pnucene.2017.01.007

(28 September 2012). Belarus, aided by Russia and Broke, Europe's Last Dictatorship Proceeds with NPP. Nuclear Intelligence Weekly (NIW).

Nuclear Power in India. (2010, November 30). Retrieved from World Nuclear Association: http://www.world-nuclear.org/info/inf53.html

Nuclear Power: An Obstacle to Rapid Development. (2009, May 27). Retrieved from Greenpeace Climate Vision: http://www.greenpeace.org/raw/content/international/press/reports/greenpeaceclimate-vision.pdf

(7 November 2014). Ostrovets plant meets construction safety rules.

ENEC. (2009, September 27). UAE Selects Korea Electric Power Corp as Prime Teams as Prime Contractor for Peaceful Nuclear Power. Retrieved February 2015, from http://www.enec.gov.ae/media-centre/news/content/uae-selects-korea-electric-power-corp-asprime-team-as-rpime-contractor-fo.

Prime Minister John Howard, "Uranium Mining and Nuclear Energy: A Way Forward for Australia", Media Release. (2007, April 28). Australia.

Ennison, I., Akiti, T., Amponsah, P., Osae, S., \& Gbadago, J. (2012). Determination of Suitable Sites for Nuclear Power Plants in Ghana: -The Issues Involved. Environmental Research, Engineering and Management, 62(4), 30-38.

Messel, H. (1953, December). Nuclear Power for Australian Industry, Australian Institute of Policy Science. Retrieved January 23, 2014, from http://www.jstor.org/stable/41317627.

Riffkin, R. (2016, March 2-6). For First Time, Majority in U.S. Oppose Nuclear Energy. Retrieved from Gallup: http://www.gallup.com/poll/190064/first-time-majority-oppose-nuclear-energy.aspx

Anderson, M. (1979, June 1). Australian Gallup Polls. Do you favour or oppose the construction of nuclear power stations in Australia? Australia.

Basri, N. A. (n.d.). Selection of possible candidate area for nuclear power plant in Johor, Malaysia. J. Nucl. Relat. Technol, 9, 56-63.

Shafer, W. G. (1967). Five Years of Nuclear Power at McMurdo Station. In Antarctic Journal of the United States (p. 38). Office of Antarctic Programs.

Sharon Mascher, S. L. (n.d.). TOO HOT TO HANDLE? URANIUM AND NUCLEAR POWER IN AUSTRALIA'S ENERGY MIX.

Vandenhove, H., Sweeck, L., Vives i Batlle, J., Wannijn, J., Van Hees, M., Camps, J., . . L Lance, B. (2013). Predicting the environmental risks of radioactive discharges from Belgi an nuclear power $\begin{array}{lllll}\text { plants. Journal of } & \text { Environmental }\end{array}$ doi:http://doi.org/10.1016/j.jenvrad.2013.07.004

(15 October 2012). Lithuanians send nuclear plant back to drawing board. Reuters.

France's Nuclear Industry Dream Faces Melt-Down At Expenses Of State Coffers, Tax Payers. (2015, June 4). Retrieved June 8, 2015, from http://www.forbes.com/sites/marcelmichelson/2015/06/04.

Sun, C., Lyu, N., \& Ouyang, X. (2014). Sustainability. Chinese Public Willingness to Pay to Avoid Having Nuclear Power Plant in the Neighborhood.

Tuan, L. M. (2016). Licensing Process for the First Nuclear Power Plant in Vietnam Status, Challenges and Future Works 
United States Environmental Protection Agency. (2006, April). Retrieved from www.epa.gov/radtown/antiques/html.

(March 2003). International Energy Annual 2001, Energy Information Administration report. Washington, DC: U.S. Department of Energy.

Attia, S. I. (2015). The influence of condenser cooling water temperature on the thermal efficiency of a nuclear power plant. Annals of Nuclear Energy, 80, 371-378. doi:http://doi.org/10.1016/j.anucene.2015.02.023

Chater, J. (2005). A history of nuclear power. Focus on Nuclear Power Generation, 29-34.

World Nuclear Association. (2017, February). Nuclear Power in the European Union. Retrieved from World Nuclear Association: http://www.world-nuclear.org/information-library/countryprofiles/others/european-union.aspx

Yamada, M., \& Iguchi, T. (n.d.). Public Acceptance (PA) Activities of Nuclear Power in Japan.

E. V. Giusti and E.L. Meyer, "Water Consumption by Nuclear Powerplants and Some Hydrological Implications," U.S. Department of the Interior, Geological Survey Circular 745, 1977

Water \& Sustainability (Volume 3): U.S. Water Consumption for Power Production - The Next Half Century," Electric Power Research Institute, Technical Report 1006786, March 2002 